\title{
Bikuspidalizace unikuspidální aortální chlopně jako alternativa její náhrady
}

\author{
Jaroslav Hlubocký1, Hans-Joachim Schäfers², Pavel Žáček³, Jan Vojáček³, Tomáš Paleček, Alfred Hornig', \\ Lenka Skalická ${ }^{4}$ Jaroslav Lindner ${ }^{1}$ \\ 'Il. chirurgická klinika - kardiovaskulární chirurgie, Všeobecná fakultní nemocnice a 1. lékařská fakulta Univerzity Karlovy, Praha, \\ Česká republika, \\ ${ }^{2}$ Klinik für Thorax- und Herz-Gefäßchirurgie, Universitätsklinikum des Saarlandes, Deutschland, \\ ${ }^{3}$ Kardiochirurgická klinika, Kardiocentrum, Fakultní nemocnice Hradec Králové a Lékařská fakulta v Hradci Králové Univerzity Karlovy \\ $\checkmark$ Praze, Hradec Králové, Česká republika \\ ${ }^{4}$ II. interní klinika kardiologie a angiologie, Všeobecná fakultní nemocnice a 1. lékařská fakulta Univerzity Karlovy, Praha, \\ Česká republika
}

Adresa: MUDr. Jaroslav Hlubocký, II. chirurgická klinika - kardiovaskulární chirurgie, VFN a 1. LF UK, U Nemocnice 2, 12800 Praha 2, Česká republika, e-mail: jaroslav.hlubocky@vfn.cz

Autoři prezentují př́pad 34leté pacientky, která byla na naše pracoviště přijata pro kritickou ischemii pravé dolní končetiny. Urgentní angiografické vyšetření prokázalo embolizační uzávěr pravé povrchové stehenní tepny, který byl současně úspěšně ošetřen aspirací a lokální trombolýzou. Při pátrání po zdroji embolizace byla při echokardiografickém vyšetření zjištěna př́itomnost unikuspidální chlopně s významnou stenózou s indexovanou plochou ústí $0,61 \mathrm{~cm}^{2} / \mathrm{m}^{2}$ a středně významnou regurgitací (obrázek 1). Pacientka byla indikována k časnému kardiochirurgickému výkonu. Hrudník byl otevřen střední sternotomií, mimotělní oběh byl zaveden kanylací aorty a pravé síně. Aortotomie byla provedena příčně, $7 \mathrm{~mm}$ nad sinotubulární junkcí (obrázek 2). Morfologický nález na chlopni odpovídal echokardiografickému vyšetření. Unikuspidální aortální chlopeň měla normálně vysokou zadní komisuru (levo-nekoronární), zbylé dvě komisury byly rudimentární zhruba $8 \mathrm{~mm}$ pod ústím pravé koronární tepny, z pravolevé komisury prominovaly četné kalcifikace jak do aortálního kořene, tak i na komorovou stranu, které byly velmi pravděpodobně př́činou systémové embolizace. Veškerá kalcifikovaná tkáň byla resekována (obrázek 3). $\mathrm{K}$ rekonstrukci chlopně byl použit autologní perikard fixovaný $0,6 \%$ glutaraldehydem. Cílem bylo vytvořit bikus-

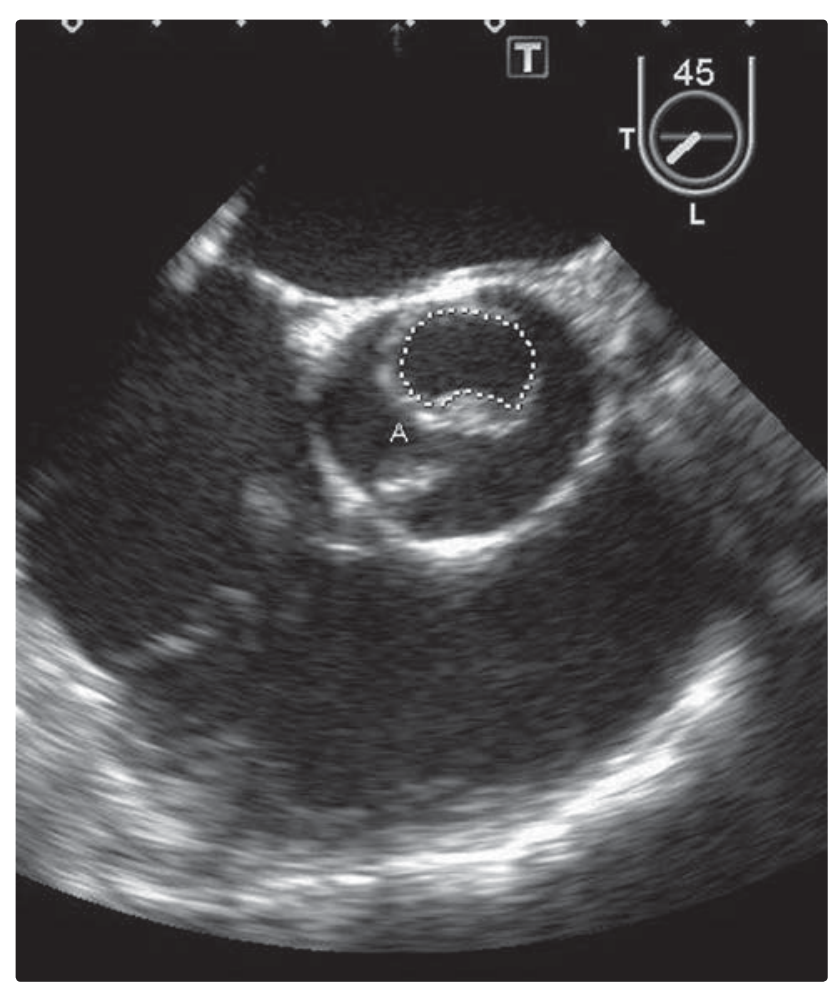

Obrázek 1 Předoperační echokardiografie - planimetrie aortálního ústí 


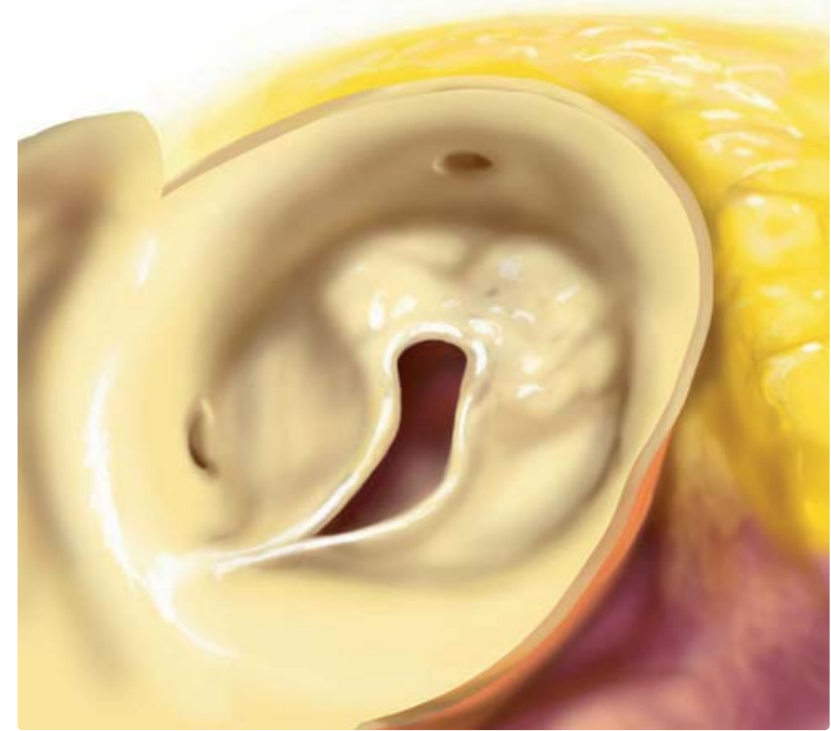

Obrázek 2 Unikuspidální aortální chlopeň po aortotomii

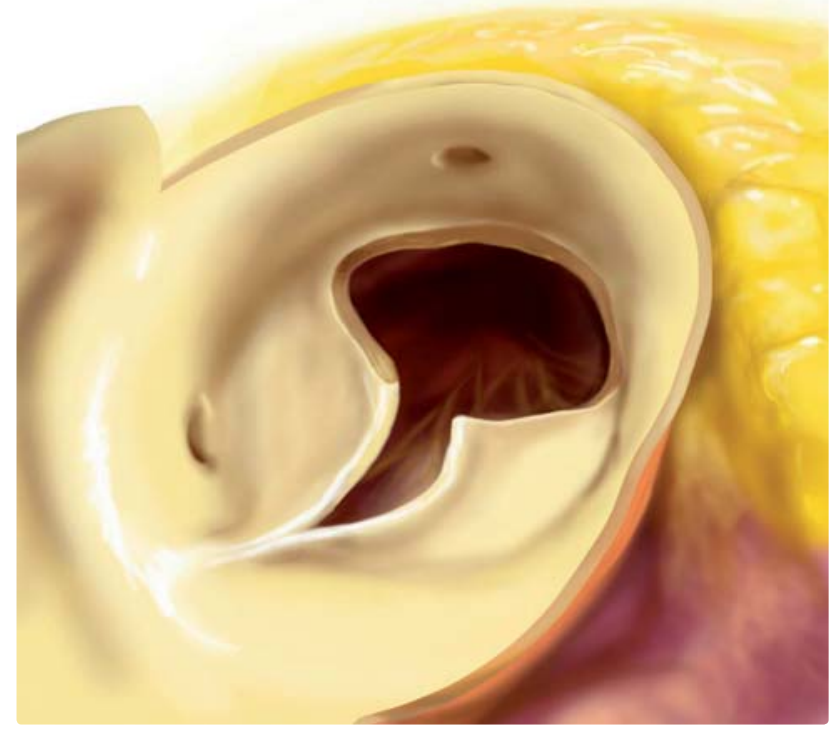

Obrázek 3 Rozsah resekce kalcifikovaných cípů

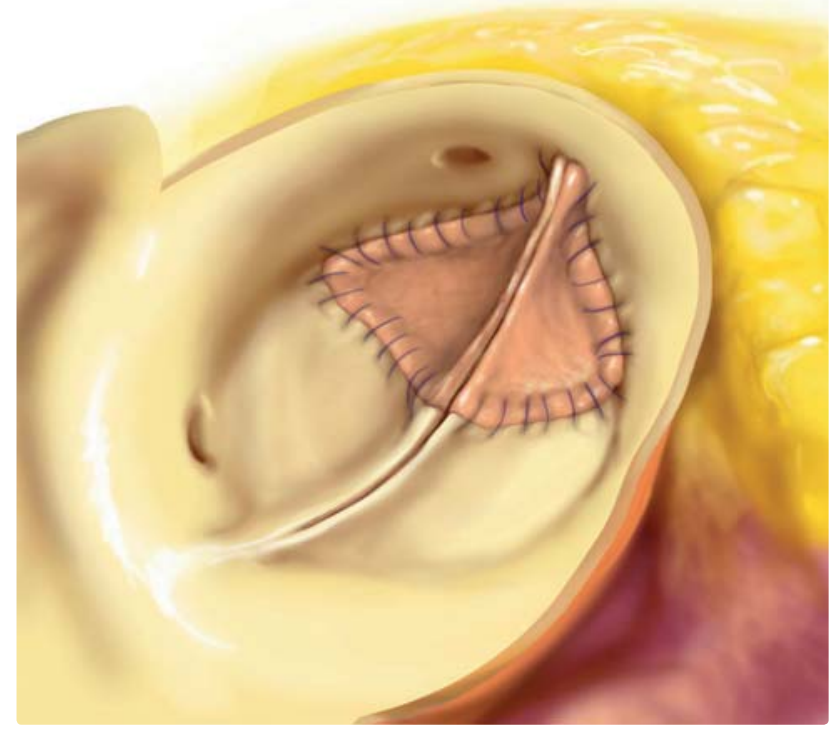

Obrázek 4 Bikuspidalizace autologním perikardem

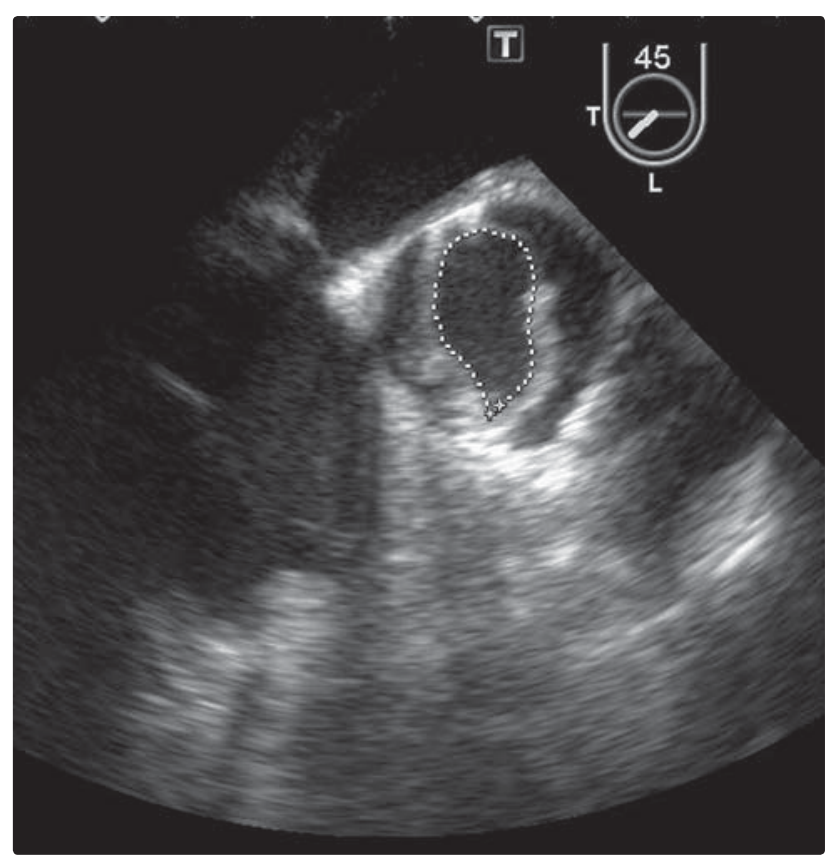

Obrázek 5 Pooperační echokardiografie - planimetrie aortálního ústí

pidální konfiguraci chlopně se dvěma normálně vysokými komisurami. Podíl autologního perikardu na obou cípech byl zhruba jedna třetina (obrázek 4).

Pooperační průběh byl nekomplikovaný a pacientka byla 6. pooperační den propuštěna domů. Kontrolní echokardiografické vyšetření při propuštění i v odstupu jednoho měsíce od výkonu prokázalo pouze stopovou aortální regurgitaci $\mathrm{s}$ bikuspidální otevírací charakteristikou chlopně s plochou ústí 2,5 $\mathrm{cm}^{2}$ (obrázek 5).

Unikuspidální aortální chlopeň je diagnostikována vzácně. Její výskyt ve větších echokardiografických souborech dospělé populace činí $0,02 \%$. Její přítomnost je velmi často spojena s dilatací ascendentní aorty (48 \%). ${ }^{1}$ Unikuspidální aortální chlopeň bývá nejčastěji intervenována do 40 let věku, přičemž rekonstrukční výkon, pokud je technicky možný, je preferován vưči implantaci chlopenní náhrady. ${ }^{2}$ Technika bikuspidalizace unikuspidální chlopně je však využívána teprve od roku 2003 a její dlouhodobá trvanlivost představuje dosud nezodpovězenou otázku. ${ }^{3}$

\section{Literatura}

1. Novaro GM, Mishra M, Griffin BP. Incidence and echocardiographic features of congenital unicuspid aortic valve in an adult population. J Heart Valve Dis 2003;12:674-678.

2. Aicher D, Fries R, Rodionycheva $S$, et al. Aortic valve repair leads to a low incidence of valve-related complications. Eur J Cardiothorac Surg 2010:37:127-132.

3. Schäfers HJ, Aicher D, Riodionycheva $S$, et al. Bicuspidization of the unicuspid aortic valve: a new reconstructive approach. Ann Thorac Surg 2008;85:2012-2018. 